\title{
SURFACE PRE-TREATMENT OF ALUMINUM ALLOYS IMPROVING SURFACE ADHESIVE PROPERTIES
}

\author{
Jaromír WASSERBAUER, Jan PIKNER \\ Materials Research Centre, Faculty of Chemistry, Brno University of Technology, Brno, Czech Republic, EU, \\ wasserbauer@fch.vut.cz
}

https://doi.org/10.37904/metal.2019.890

\begin{abstract}
Adhesive bonding is a method often used for bonded joints of aluminum alloys preparation. The surface pretreatment is strongly influencing bonded joints shear strength. The surface of two aluminum alloys (AlMg3, AlMgSi) subjected for bonded joints preparation were surface pre-treated using one commercially used and two laboratory prepared solutions. Scanning electron microscopy including chemical composition analysis and tensile shear test for analysis of the pre-treated aluminum alloys were used. Surface of both the examined alloys after pre-treatment exhibited similar character regardless analyzed material and used pre-treatment solution. Tensile shear test revealed differences between individual solutions used for material surfacepretreatment. AIMgSi alloy reached higher shear strength then the AlMg3 alloy. Exposure of the bonded joints to the climate conditions simulated in a climate chamber revealed and decisive influence of the environment to the adhesive properties of individual materials, however, also differences in the used adhesives were observed and were shown to be more significant than the pre-treatment conditions.
\end{abstract}

Keywords: Aluminum alloys, surface pre-treatment, adhesive properties, shear tensile test, climatic test

\section{INTRODUCTION}

Aluminum is the most common metal in the earth's crust and is the second most important metal after iron [1]. Due to the good mechanical properties, light weight and quite good corrosion resistance are aluminum and its alloys used for wide range of applications, such as transport, electrotechnic and food industry [2].

Adhesive technology is due to its simplicity very useful tool applied in many industries, especially in the field of aviation and transport industry. The simplest way to prepare a bonded joint is to create an adhesive layer between two adherents and apply pressure to the overlap region for a specific time needed to cure the adhesive [5]. A large number of adhesives are based on epoxy resins, which are usually colorless to yellowish substances, generally containing more than one epoxy group. This group is reactive with a large number of compounds to form cross-linked macromolecular products with high adhesion to most of materials [6].

For quality adhesive bond it is necessary to modify the surface of the glued parts. Increased surface roughness of glued parts improves the bond quality due to the higher surface area participating on the bond. As a pretreatment of aluminum alloys, degreasing and subsequent passivation are used. The alkaline and acidic removal of grease and other impurities from the parts surface is a conventional method for surface pretreatment. The reason is a good availability of the used materials, such as hydroxides, acids, carbonates or even active surfactants. Immersion and spraying are the most used ways for the aluminum alloys surface degreasing (a pressured spray of degreasing agent solution is used). The aluminum surface is passivated in air to form an $\mathrm{Al}_{2} \mathrm{O}_{3}$ layer. Passivation is a chemical or electrochemical (electrochemical oxidation = anodization) surface treatment, improving the resistance of the surface of the metal to the corrosive environment. The passivation layer is very brittle and therefore its protective effectiveness is relatively limited. Due to the fact that aluminum components surface passivation is often used for in-process protection of materials during transport and storage before post-treatment, passivation is usually classified as surface pretreatment [3]. Due to the surface roughness and stability, the conditions of the pre-treated surface 
subsequently influence the affinity of post-treatment surface coverage layers to the base metal. Several commercial products can be used for aluminum alloys components surface pre-treatment via anodization, however, most of the producer do not provide their solution chemical composition.

Some industrial companies dealing with surface treatment, given as a functional layer for further operations conversion coating based on titanium or zirconium [4].

The surface of two aluminum alloys (AIMg3, AIMgSi) subjected for bonded joints preparation were surface pretreated using one commercially used, [4], and two laboratory prepared solutions. The pre-treated surfaces were analyzed in terms of scanning electron microscopy and chemical analysis. Subsequently the bonded joints using two types of adhesive were prepared. The bonded joints were also subjected to climatic stress (simulating operating environment conditions) and the joints were subsequently tested by shear tensile testing. The two pre-treated surfaces adopting the laboratory prepared solutions were compared with the materials pre-treated by commercial solution.

\section{EXPERIMENTAL MATERIALS AND METHODOLOGY}

\subsection{Experimental materials}

AlMg3 (AW-5754), aluminum alloy is heat-nonhardenable alloy belonging to the 5000 series. The strength of the alloy can be increased by cold deformation, however, resulting in a further reduction of the alloy formability. AlMg3 is characteristic by excellent corrosion resistance to seawater and atmosphere. It is very well weldable by all common aluminum welding processes and can be heat treated by annealing under certain conditions. The chemical composition of the examined alloy is shown in Table 1. The microstructure of AlMg3 created by polyhedral grains and numerous intermetallic particles can be seen in Figure 1a.

AlMgSi (AW-6060) aluminum alloy is precipitation hardenable. Due to the alloy good formability and good strength in the cured state, it is mainly used in the production of various profiles (up to $80 \%$ of aluminum profiles are 6000 series). The profiles are usually delivered to the customers in a thermally cured state. Corrosion resistance is relatively good and can be even increased by anodic oxidation of the products. The alloy is weldable by all common aluminum welding processes, however, the weld has a lower strength than the base material. After hot curing is the alloy well machinable. The chemical composition of the examined alloy is shown in Table 2. The microstructure of the material created by polyhedral grains can be seen in Figure 1b.
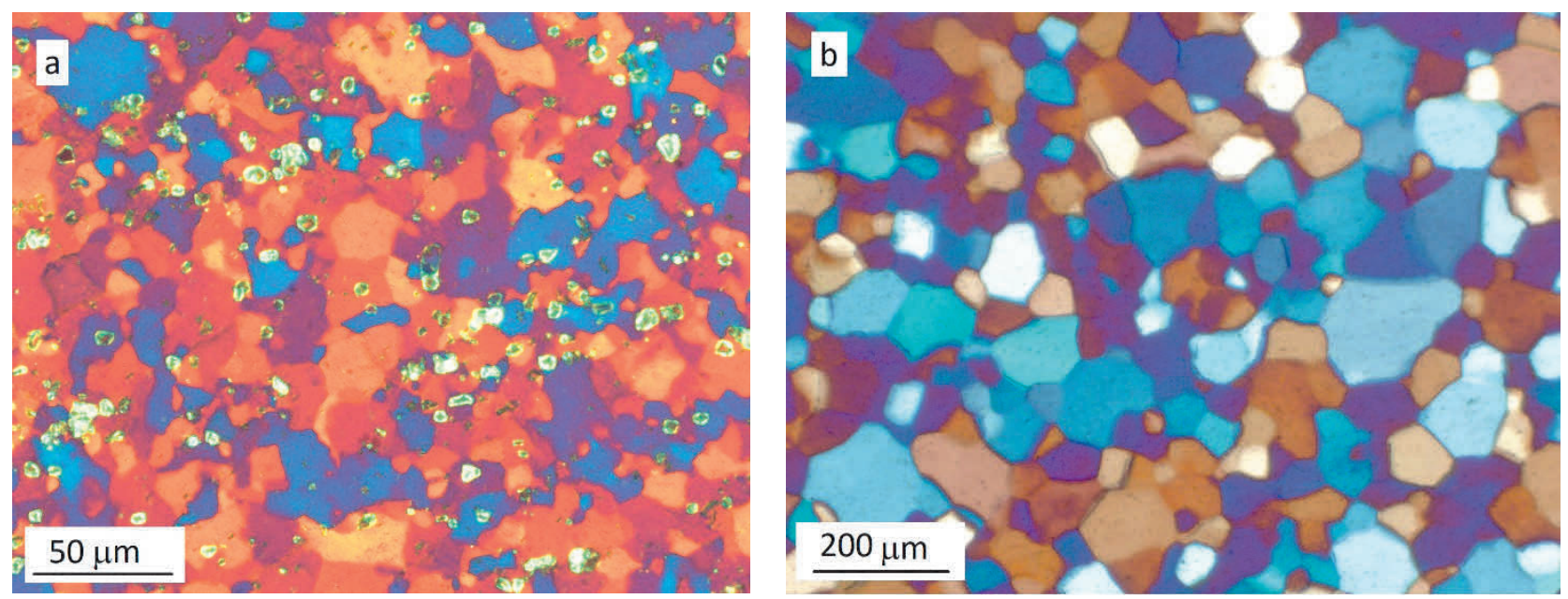

Figure 1 The microstructure of the alloy

a) AlMg3, b) AlMgSi, polarized light, light optical microscope 
Table 1 Chemical composition of AlMg3 alloy, wt\% (According to ASTM)

\begin{tabular}{|c|c|c|c|c|c|c|c|c|c|}
\hline $\mathrm{Si}$ & $\mathrm{Fe}$ & $\mathrm{Cu}$ & $\mathrm{Mn}$ & $\mathbf{M g}$ & $\mathbf{C r}$ & $\mathbf{Z n}$ & $\mathbf{T i}$ & Other & $\mathrm{Al}$ \\
\hline 0.4 & 0.4 & 0.1 & 0.5 & $2.6-3.6$ & 0.3 & 0.2 & 0.15 & 0.15 & Remain \\
\hline
\end{tabular}

Table 2 Chemical composition of AIMgSi alloy, wt\% (According to ASTM)

\begin{tabular}{|c|c|c|c|c|c|c|c|c|c|}
\hline $\mathbf{S i}$ & $\mathbf{F e}$ & $\mathbf{C u}$ & $\mathbf{M n}$ & $\mathbf{M g}$ & $\mathbf{C r}$ & $\mathbf{Z n}$ & $\mathrm{Ti}$ & Other & Al \\
\hline $0.3-0.6$ & $0.1-0.3$ & 0.1 & 0.1 & $0.35-0.6$ & 0.05 & 0.15 & 0.1 & 0.15 & Remain \\
\hline
\end{tabular}

\subsection{Surface pre-treatment and characterization}

The experimental alloys were cut into the samples of $50 \times 50 \mathrm{~mm}$ and $1.5 \mathrm{~mm}$ thick. After the surface preparation three baths for the alloys surface passivation (pre-treatment) were used - commercial one (HENKEL company, reference) and laboratory prepared baths. For all the solutions used, the immersion time was $60 \mathrm{~s}$ and the same surface pretreatment before the alloys final treatment was used.

The first passivation bath (reference) was prepared according to the instructions for the commercial preparation used - allegedly forming a titanium conversion coating. Aluminum samples were ground with 800 grit sandpaper and degreased with a commercial suspension. A bath of $1.5 \mathrm{wt} \%$ of the degreasing solution was used at $60^{\circ} \mathrm{C}$ with a 30 second immersion time. The samples were afterward cleaned by distilled water and isopropylalcohol at the end. The sample was then dried with hot air.

The concentration of two passivation solutions prepared in the laboratory was: $0.2 \mathrm{M} \mathrm{H}_{3} \mathrm{PO}_{4}$ with the addition of $0.75 \mathrm{ml} / /$ hydrofluoric acid, and $0.1 \mathrm{M} \mathrm{H}_{2} \mathrm{SO}_{4}$ with the same amount of hydrofluoric acid

The surface of the pre-treated samples was evaluated using a scanning electron microscope (SEM, Zeiss EVO model LS10). The elemental composition of the passivated surface was analyzed by Energy dispersive X-ray spectroscopy (EDS, model OXFORD INSTRUMENTS X-MAX $80 \mathrm{~mm}^{2}$ ). To determine the presence of the titanium conversion coating, the commercially treated samples by X-ray Photoelectron Spectrometer (XPS, model Kratos AXIS Ultra) were analyzed.

\subsection{Strength of bonded joints}

Bonded joints were prepared on pre-treated samples of AIMg3 and AIMgSi alloys. The preparation of the bonded joints on the pre-treated samples was carried out according to the industrial company IFE standards. Acralock SA 10-05 BLK and Redux 609 adhesives were used for the bonds preparation. After using Acralock adhesive, the samples were placed in the fixture for 24 hours, while the adhesive cured at room temperature. In the case of the Redux adhesive, the samples were glued, placed in the jig and subsequently moved with the jig to the press, where the adhesive at 20 bar and $130^{\circ} \mathrm{C}$ was cured. The curing time was 45 min.

Half of the samples with bonded joints were placed in a climate chamber for two weeks. The temperature regime for each week was set to $70{ }^{\circ} \mathrm{C}$ for half an hour at $98 \%$ humidity followed by 144.5 hours at $70{ }^{\circ} \mathrm{C}$ with $98 \%$ humidity. This was followed by a one hour drop to $-20{ }^{\circ} \mathrm{C}$ with a 15 hours dwell at this temperature and $0 \%$ humidity.

The strength of the bonded joints was tested on a Zwick/Roell Z010 tensile machine at the tension speed of 1 $\mathrm{mm} / \mathrm{min}$.

\section{RESULTS AND DISCUSSION}

\subsection{Surface characterization of the pre-treated samples}

Similar surface roughness was observed analyzing the surfaces of the AlMg3 samples pre-treated with different baths, Figure 2. The elemental composition of the pre-treated surface, as determined by the EDS 
method, corresponds to the reference sample Table 3. The chemical composition of the surface of the pretreated samples seems similar and no significant differences due to the used pre-treatment bat were observed. The same character was observed also for the AIMgSi samples. Also, in this case, no significant differences in the chemical composition of the pre-treated surface were observed.
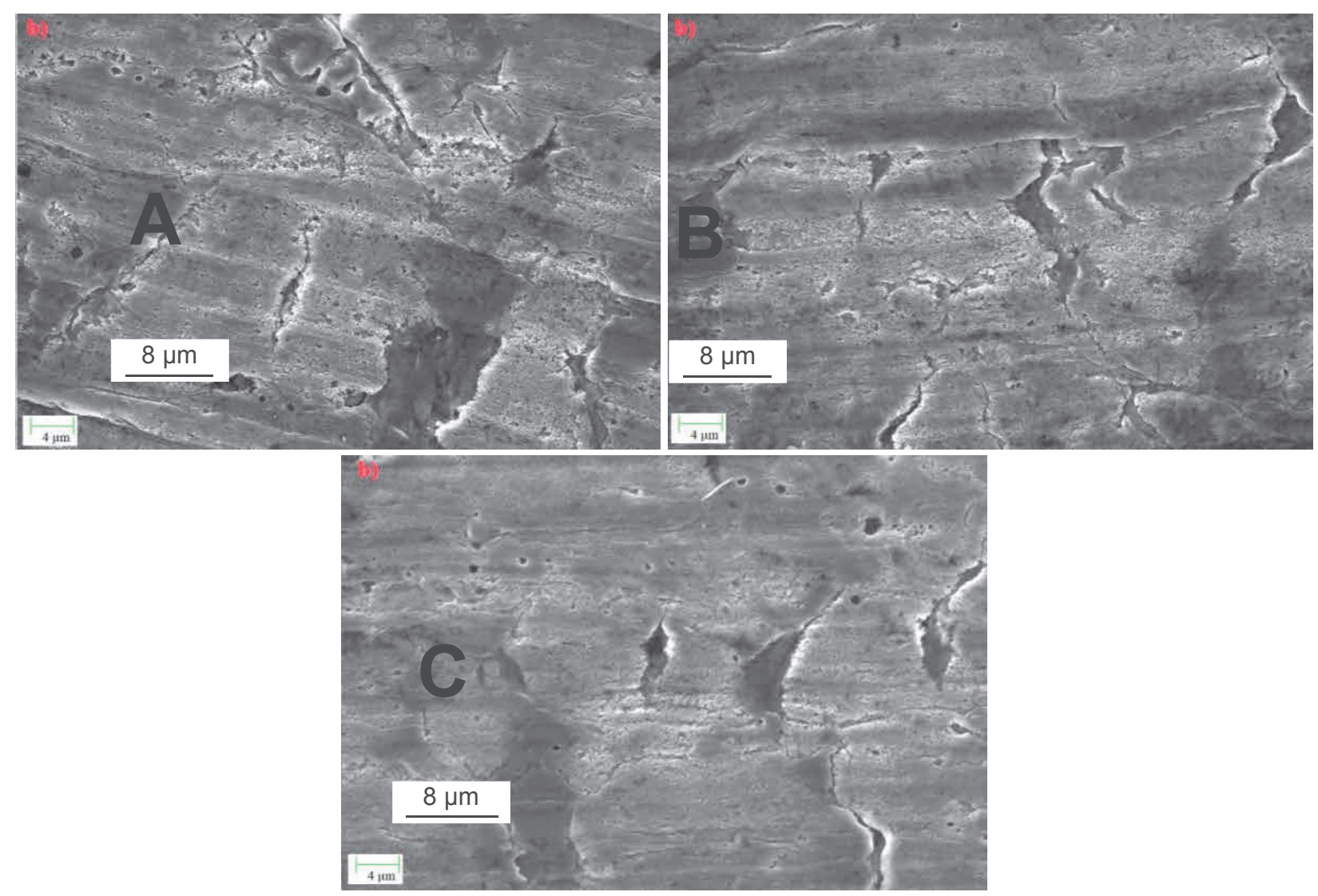

Figure 2 AIMg3 alloy samples surface after pre-treatment, A) commercially pre-treated surface, B) $0.2 \mathrm{M} \mathrm{H}_{3} \mathrm{PO}_{4}+0.75 \mathrm{ml} / \mathrm{l} \mathrm{HF}$ and C) $0.1 \mathrm{M} \mathrm{H}_{2} \mathrm{SO}_{4}+0.75 \mathrm{ml} / \mathrm{l} \mathrm{HF}$, SEM

Table 3 Elemental composition (wt\%) determined by EDS

\begin{tabular}{|c|c|c|c|}
\hline AlMg3 sample pre-treated by & Commercial bath & $\mathrm{H}_{3} \mathrm{PO}_{4}$ & $\mathrm{H}_{2} \mathrm{SO}_{4}$ \\
\hline $\mathrm{Al}$ & 90.8 & 89.1 & 89.8 \\
\hline $\mathrm{C}$ & 3.8 & 5.5 & 4.6 \\
\hline $\mathrm{Mg}$ & 3.1 & 3.0 & 3.1 \\
\hline $\mathrm{O}$ & 1.9 & 2.0 & 2.0 \\
\hline $\mathrm{Si}$ & 0.2 & 0.2 & 0.3 \\
\hline $\mathrm{F}$ & 0.2 & 0.2 & 0.2 \\
\hline
\end{tabular}

\subsection{Strength of bonded joints}

The strength of all bonded joints was tested at a loading speed of $1 \mathrm{~mm} / \mathrm{min}$. All average shear strengths and error values were calculated from five measurements. The obtained results are shown in Table 4.

From the obtained values of the shear strengths of the bonded joints can be seen that the bonds are stronger in the case of the AIMg Si alloy when compared to the AlMg3 alloy. 
Table 4 Shear strength results for the pre-treated aluminum alloys bonded joints

\begin{tabular}{|c|c|c|c|c|}
\hline Alloy & Adhesive & Pretreatment & $\mathbf{R}_{\mathrm{m}}[\mathrm{MPa}]$ & $2 \sigma$ \\
\hline \multirow{12}{*}{ AlMg3 } & \multirow{6}{*}{ Acralock } & commercial & 18.7 & 0.1 \\
\hline & & $\mathrm{H}_{2} \mathrm{SO}_{4}$ & 18.9 & 0.5 \\
\hline & & $\mathrm{H}_{3} \mathrm{PO}_{4}$ & 19.1 & 0.5 \\
\hline & & commercial + climate & 18.4 & 0.5 \\
\hline & & $\mathrm{H}_{2} \mathrm{SO}_{4}+$ climate & 18.4 & 0.6 \\
\hline & & $\mathrm{H}_{3} \mathrm{PO}_{4}+$ climate & 18.1 & 0.2 \\
\hline & \multirow{6}{*}{ Redux 609} & commercial & 18.3 & 0.9 \\
\hline & & $\mathrm{H}_{2} \mathrm{SO}_{4}$ & 18.0 & 1.2 \\
\hline & & $\mathrm{H}_{3} \mathrm{PO}_{4}$ & 19.3 & 3.3 \\
\hline & & commercial + climate & 13.3 & 1.1 \\
\hline & & $\mathrm{H}_{2} \mathrm{SO}_{4}+$ climate & 14.9 & 1.1 \\
\hline & & $\mathrm{H}_{3} \mathrm{PO}_{4}+$ climate & 13.8 & 1.6 \\
\hline \multirow{6}{*}{ AlMgSi } & \multirow{6}{*}{ Redux 609} & commercial & 30.2 & 7.5 \\
\hline & & $\mathrm{H}_{2} \mathrm{SO}_{4}$ & 34.3 & 2.3 \\
\hline & & $\mathrm{H}_{3} \mathrm{PO}_{4}$ & 36.0 & 2.3 \\
\hline & & commercial + climate & 18.0 & 3.1 \\
\hline & & $\mathrm{H}_{2} \mathrm{SO}_{4}+$ climate & 20.6 & 4.9 \\
\hline & & $\mathrm{H}_{3} \mathrm{PO}_{4}+$ climate & 20.8 & 3.3 \\
\hline
\end{tabular}

In the case of AIMg3 alloy, no significant influence of the used pre-treatment bath on the bonding shear strength was observed, regardless of the used adhesive at dry conditions. However, the laboratory prepared solutions seems to slightly increase the bonded joints strength when compared to the commercially used technology. Only a minor effect of the exposure in the climate chamber on the bonding strength in the case of Acraloc adhesive was observed. However, the quite significant influence of climate exposure on the bonding strength of the Redux 609 bonded joints was observed. Taking into account the same surface roughness of the pretreated samples surfaces, the Redux 609 seems to be sensitive on the humidity.

In the case of the AlMgSi alloy only the Redux 609 for the bonded joints preparation was used. The laboratory prepared solutions used for the samples surface pre-treatment seems to be more effective from the bonded joints strength point of view. Comparing to the commercially used solution. The positive influence of the laboratory prepared baths for the samples surface pre-treatment on the strength properties seems to be more significant than for the AIMg3 alloy. In this case, a significant influence of the climate on the bonded joints strength was observed.

The differences could be attributed to the reinforcing fabric in Redux 609, which can cause water transport to the bonded joint and consequently to the joint degradation.

\subsection{Surface element analysis}

Measurement of the elemental composition from the first $10 \mathrm{~nm}$ of the surface of the AlMg3 sample pre-treated with the commercial suspension was performed by XPS, Figure 3 . However, the presence of a titanium layer (declared by the producer), which should ensure the bond strength, was not detected.

Resulting titanium content 2.28 at.\% (Figure 3 ) to aluminum was calculated only after deliberately inserting titanium into the resulting spectrum. However, the amount of Ti determined by XRD does not correspond to the producer. 


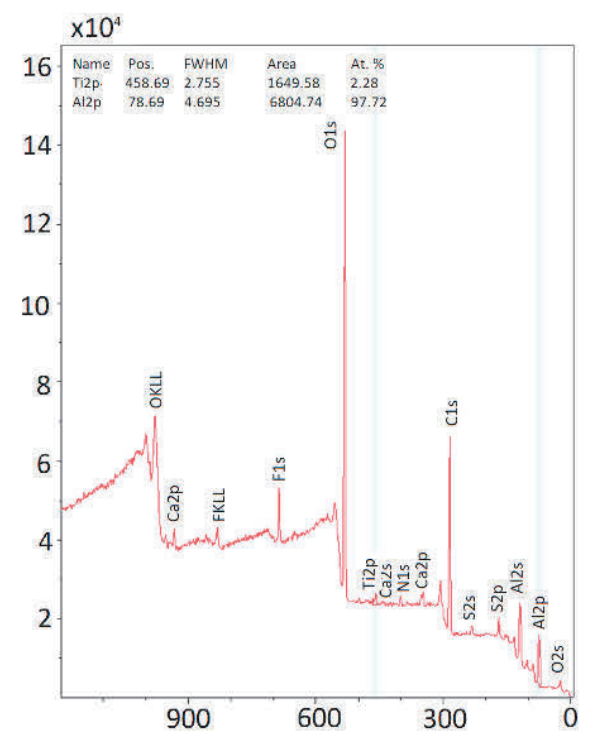

Figure 3 XPS spectrum of the sample treated by commercial means

\section{CONCLUSION}

The work was focused on the optimization of the surface pre-treatment of aluminum alloys intended for bonding. Optimized surface pre-treatments using laboratory prepared solutions were compared with a commercial product. The results of the work can be summarized as follows:

- $\quad$ Based on the observation and surface samples analysis in terms of SEM, EDS, XPS and the resulting shear strength values, it has been found that the laboratory prepared solutions used for the alloys surface pre-treatment seems to be more effective than the commercial product.

- $\quad$ Both the used laboratory prepared solution for aluminum alloys pre-treatment, $0.1 \mathrm{M}$ sulfuric acid with the addition of $0.75 \mathrm{ml} / \mathrm{l}$ of hydrofluoric acid or $0.2 \mathrm{M}$ orthophosphoric acid with the addition of $0.75 \mathrm{ml} / \mathrm{l}$ hydrofluoric acid, can replace the commercially used solution reaching the same, or slightly increased shear strength of the bonded joints.

- Surface layer created on the samples using the commercial composition of the solution for the surface pre-treatment does not consist titanium-based passivation layer, as indicated by the producer.

\section{ACKNOWLEDGEMENTS}

This work was supported by project Nr. L01211, Materials Research Centre at FCH BUTSustainability and Development (National Programme for Sustainability I, Ministry of Education, Youth and Sports).

\section{REFERENCES}

[1] MICHNA, Štefan et al. Encyklopedie hliníku. 1st ed. Děčín: Alcan Děčín Extrusions, 2005. p. 700.

[2] VOJTĚCH, Dalibor. Kovové materiály. 1st ed. Praha: Vydavatelství VŠCHT, 2006. p. 185.

[3] TULKA, Jaromír. Povrchové úpravy materiálů. 1st ed. Brno: Vysoké učení technické v Brně, Fakulta chemická, 2005. p. 136.

[4] HENKEL Corporation [online]. 2019. [viewed 2019-04-30]. Available from: http://www.bonderite.com/en/technologies/light-metal-finishing/chrome-free-conversion-coatings.html

[5] MITTAL, Kash L. Progress in adhesion and adhesives. 1st ed. Hoboken, New Jersey: Scrivener Publishing-Wiley, 2015. p. 496.

[6] DUCHÁČEK, Vratislav. Polymery: výroba, vlastnosti, zpracování, použiti. 2nd ed. Praha: Vydavatelství VŠCHT, 2006. p. 278. 